\title{
Konflik Sosial dalam Komunitas Virtual di Kalangan Remaja
}

\author{
Dony Arung Triantoro \\ Pascasarjana, Universitas Islam Negeri (UIN) Sunan Kalijaga, Yogyakarta, Indonesia. \\ Email: arungdony73@gmail.com
}

\begin{abstract}
The presence of virtual communities further facilitates interaction between individuals or groups. Interaction in the form of production, distribution, and consumption of messages in the virtual community has the chance of conflict. This study aims to analyze the causes of conflicts in virtual communities and how to overcome them. This study uses a qualitative approach. Data is collected through online participation, interviews, documentation and literature studies relevant to this study. This study found that social conflict in the virtual community of adolescents was caused by misunderstandings in understanding the text or opinions, sensitivity to symbols, time and community functions, cyberbullying, SARA issues and egocentric posts on differences in the background of community members. This conflict makes members of the virtual community fragmented into three groups, namely conservative, liberal and silent readers. There are various ways to deal with virtual conflicts that occur, including conciliation between perpetrators of conflict, mediation, temporarily removing actors from the virtual community to conduct detente by changing the subject or sending pictures that invite other members to laugh.
\end{abstract}

Keywords: Social Conflict, Virtual Community, Adolescent

\begin{abstract}
Abstrak.Kehadiran komunitas virtual semakin memudahkan interaksi antarindividu ataupun kelompok. Interaksi dalam bentuk produksi, distribusi dan konsumsi pesan dalam komunitas virtual tersebut berpeluang terjadinya konflik. Penelitian ini bertujuan untuk menganalisis penyebab munculnya konflik dalam komunitas virtual dan cara mengatasinya. Penelitian ini menggunakan pendekatan kualitatif. Data dikumpulkan melalui partisipasi daring, wawancara, dokumentasi dan studi literatur yang relevan dengan penelitian ini. Penelitian ini menemukan bahwa konflik sosial dalam komunitas virtual remaja disebabkan oleh kesalahpahaman dalam memahami teks atau pendapat, sensitivitas terhadap simbol, waktu dan fungsi komunitas, cyberbullying, postingan isu SARA dan egosentris terhadap perbedaan latar belakang anggota komunitas. Konflik ini membuat anggota komunitas virtual terfragmentasi menjadi tiga kelompok, yaitu kelompok konservatif, liberal dan silent reader. Ada beragam cara mengatasi konflik virtual yang terjadi, di antaranya konsiliasi antarpelaku konflik, mediasi, mengeluarkan pelaku dari komunitas virtual untuk sementara waktu hingga melakukan detente dengan cara mengalihkan pembicaraan atau mengirim gambar-gambar yang mengundang tawa anggota lainnya
\end{abstract}

Kata Kunci: Konflik sosial, Komunitas Virtual, Remaja 


\section{Pendahuluan}

Pada 1989, Timothy Berners-Lee, ahli komputer dari Inggris, menciptakan World Wide Web (WWW). Www dipandang sebagai program yang memungkinkan suara, gambar, film, dan musik dapat ditampilkan di internet. Kemampuan inilah yang menyebabkan internet menjadi lebih menarik dalam tampilan dan variasinya. Oleh karena itu, popularitas internet meningkat tajam, menggantikan media konvensional seperti surat kabar, radio, dan televisi. Saat ini, hampir semua kegiatan manusia terhubung dengan internet, termasuk interaksi sosial seharihari. Dalam hal ini, internet telah menjadi kebutuhan primer dalam aktivitas seharihari, baik sebagai sumber informasi, hiburan, edukasi bahkan pekerjaan dan bisnis.

Data survei yang dilakukan oleh Asosiasi Penyelenggara Jasa Internet Indonesia (APJII) pada 2017 menunjukkan bahwa sebanyak 143,26 juta penduduk Indonesia menggunakan internet dalam kehidupan sehari-hari mereka. Dari keseluruhan pengguna internet tersebut, sekitar 89,35\% menjadikan media sosial sebagai jenis yang paling sering diakses untuk chatting. Jika dilihat dari usia, maka pengguna internet didominasi oleh usia 1318 tahun (75,50\%) dan usia 19-34 tahun (72,23\%). Data ini menunjukkan tingginya antusias remaja untuk mengakses media sosial. Ketertarikan remaja tersebut semakin tinggi karena didukung oleh berbagai jenis aplikasi chating dalam media sosial seperti whatsapp, blackberry messenger (BBM), facebook, dan sebagainya. Melalui aplikasi tersebut, seorang remaja dapat memperluas jaringan pertemanan, memperkuat hubungan emosional dengan orang lain bahkan bertemu dengan teman lama dalam satu komunitas di dunia maya (komunitas virtual) (Simangunsong, 2017). Menurut Jasmadi (2008), komunitas virtual disebut sebagai komunitas daring, yakni sekelompok orang yang berkomunikasi menggunakan internet sebagai media utama, dan tidak mengandalkan pertemuan langsung secara fisik. Komunitas virtual adalah area di mana orang-orang dapat berbagi pendapat dan berinteraksi secara daring (Laudon dan Traver, 2016).

Komunitas virtual terbentuk dari kumpulan anggota dalam jaringan internet yang terjalin atas motif tertentu seperti hobi, cara pandang, kebutuhan, dan kesamaan latar belakang (pendidikan, budaya, agama, profesi dan sebagainya). Pada dasarnya, pembentukan komunitas maya juga diinisiasi oleh faktor-faktor yang mendorong terbentuknya komunitas nyata pada umumnya. Di mana masyarakat nyata membentuk organisasi yang dilatarbelakangi oleh faktor kesamaan (Rangga, 2015: 3).

Melalui komunitas virtual dalam media sosial, seseorang tidak hanya sebagai konsumen informasi, tetapi juga memproduksi informasi untuk disebarkan kepada anggota lainnya. Dalam situasi semacam ini, seseorang dapat menjadi penerima atau konsumen informasi, tetapi, di sisi lain, seseorang dapat menjadi produsen informasi bahkan distributor informasi (Weeks and Holbert, 2013). Pola interaksi yang bersifat banyak arah itulah yang mengakibatkan remaja antusias untuk menggeluti media sosial sebagai aktivitas interaksi sosial mereka seharihari.

Salah satu fitur media sosial yang belakangan ini diminati oleh kalangan remaja adalah fitur whatsapp group. Whatsapp group menjadi primadona di kalangan remaja dalam melakukan interaksi sosial dengan teman-teman sejawat. Melalui whatsapp group, remaja dapat bertemu dan berkumpul dalam ruang maya (cyberspace) untuk saling menyapa, bertukar pikiran, sharing informasi, dan bahkan bercanda bersama. 
Kehadiran komunitas virtual (whatsapp group) mempunyai dampak positif, tapi juga negatif. Salah satu dampak negatif yang ditimbulkan oleh komunitas virtual adalah kemampuannya dalam membuka ruang konflik antaranggota. Banyak konflik sosial antarremaja diawali oleh aktivitas berkirim pesan (chatting) dan bercanda di antara anggota yang menimbulkan sensitivitas beberapa anggota. Pesan yang disampaikan tersebut sering kali dianggap sebagai kebencian (hate Specch). Di sini, ujaran kebencian dipahami sebagai suatu bentuk penghinaan (Wolfson dalam Syahputra, 2017). Penelitian Syahputra (2017) menunjukkan perang siber di media sosial telah membentuk dua polarisasi netizen. Polarisasi tersebut dapat diidentifikasi sebagai kelompok konservatif dan kelompok liberal. Kedua kelompok tersebut aktif memproduksi wacana, opini, informasi, isu, dan rumors melalui media sosial.

Ruang siber (cyberspace) membuat interaksi seseorang berlangsung secara termediasi sehingga seseorang tidak bisa memahami kondisi psikologi lawan bicaranya. Ini memicu terjadinya gap atau ketidakharmonisan terhadap interaksi sosial di ruang virtual.

Komunitas virtual yang terdiri dari berbagai model kepribadian anggota juga sering kali menampilkan citra diri (self image) masing-masing anggotanya. Setiap anggota akan selalu mempertahankan citra dirinya agar terlihat baik di hadapan anggota lainnnya. Untuk mempertahankan citra diri tersebut, terkadang, setiap anggota mengedepankan sikap egoismenya sehingga konflik menjadi semakin mudah terjadi. Di samping itu, komunitas virtual sebagai forum terbuka, berpeluang besar bagi setiap anggotanya untuk berkirim pesan atau informasi yang mengandung kebohongan (hoax). Hoax dengan mengacu pada pendapat Curtis D. Mac Dougall (dalam Syahputra, 2017) dipahami sebagai ketidakbenaran informasi yang diproduksi secara sengaja untuk membiaskan kebenaran.

Fenomena konflik di media sosial ini menarik untuk dikaji. Ini karena bukan hanya bahwa komunitas virtual mampu 'memediasi' konflik dalam realitas sosial, tapi adalah penting agar setiap anggota mengetahui konsekuensi yang ditimbulkan oleh interaksi yang dilakukan melalui komunitas virtual. Utamanya, dalam membuka ruang konflik di antara para partisipan atau anggota kelompok percakapan. Oleh karena itu, penelitian ini ingin mengkaji apa penyebab munculnya konflik di dalam komunitas virtual, dan bagaimana cara mengatasi konflik tersebut?

Komunitas virtual ada dalam kehidupan sosial yang muncul sebagai akibat kehadiran media baru. Usaha-usaha untuk mengkaji fenomena itu penting karena munculnya pergeseran konflik, dari yang awalnya dalam dunia sosial ke dalam ruang-ruang mediasi. Kajian semacam itu masih langka sehingga memahaminya akan memberikan informasi penting dalam usaha kita memahami media baru, dan kontribusinya dalam interaksi sosial di kalangan remaja.

\section{Metode Penelitian}

Penelitian ini menggunakan pendekatan kualitatif dengan memfokuskan pada fenomena sosial yang terjadi di masyarakat daring, yang secara khusus melihat tentang mengapa orang berperilaku dan berbuat seperti yang mereka lakukan (Hancock, Ockleford, \& Windridge, 2009). Lebih spesifik, penelitian kualitatif ini mengacu pada Hammersley \& Atkinson (2007) yang mempelajari data-data yang diperoleh untuk pengembangan konsep-konsep terkait konflik sosial di media sosial.

Data dikumpulkan melalui wawancara mendalam pada narasumber peneli- 
tian. Mengacu pada Wimmer dan Dominick (2014), wawancara mendalam dimaksudkan untuk mengetahui informasi dari informan secara detail. Informan yang diwawancarai adalah remaja yang tergabung dalam komunitas virtual, baik yang terlibat maupun yang tidak terlibat dalam konflik komunitas virtual mereka. Pemilihan informan mengacu pada Stokes (2016). Informan dipilih berdasarkan kelayakan dan ketersediaan akses peneliti terhadap narasumber.

Selain wawancara mendalam, pengumpulan data juga dilakukan dengan teknik observasi partisipan. Subagyo (2011) mengemukakan bahwa observasi partisipan dilakukan untuk mengamati perubahan-perubahan yang terjadi dalam komunitas virtual untuk kemudian dilakukan penilaian. Selain itu, pengumpulan data juga menggunakan teknik studi dokumentasi dan literatur. Penggunaan dokumentasi semata-mata untuk mendukung perolehan data. Data dokumentasi untuk melengkapi data yang ada (Gunawan, 2014). Penulis melakukan studi dokumentasi dengan cara mencari screnshoot percakapan (chatting) anggota saat melakukan konflik di dalam komunitas virtual mereka melalui bantuan narasumber penelitian, sedangkan studi literatur dilakukan dengan menginterpretasi data yang diperoleh dengan menggunakan literasi-literasi yang terkait.

Data-data tersebut selanjutnya diproses dalam sejumlah kategori yang mengarah pada upaya generalisasi untuk kemudian disajikan secara interpretative dan descriptive. Untuk menjaga validitas data penulis menggunakan teknik triangulasi data. Triangulasi data dilakukan dengan memanfaatkan interpretasi peneliti, sumber data, dan teori (Bungin, 2000). Selanjutnya, penulis menganalisis dengan metode deskriptif kualitatif.

\section{Hasil Penelitian dan Pembahasan}

Berdasarkan data penelitian, konflik sosial dalam komunitas virtual setidaknya diinisiasi oleh lima aspek penting, yaitu kesalahpahaman, sensitivitas, Cyberbullying, postingan isu SARA, dan egosentris dalam komunitas virtual.

\section{Kesalahpahaman dalam komunitas virtual}

Mayfield (2008) menyebutkan bahwa media sosial dapat mempermudah penggunanya untuk mengirim dan memproduksi pesan melalui jejaring sosial, media daring, dan forum dunia maya. Media sosial pada dasarnya membuka ruang kemudahan bagi seseorang untuk berinteraksi secara cepat tanpa jarak dan waktu. Stockdale dan Borovicka (2006) menyebutnya dengan kemudahan aksesibilitas.

Kemudahan mengeluarkan pendapat di media sosial tidak hanya disampaikan dalam akun pribadi, melainkan dalam komunitas virtual seperti group whatsapp, groupfacebook dan sebagainya. Komunitas virtual membantu seseorang untuk mengeluarkan aspirasinya baik dalam menilai, menanggapi ataupun mengkritik informasi yang diberikan anggota lainnya.

Jika dalam ruang nyata, seseorang enggan mengeluarkan pendapatnya karena diperhatikan langsung oleh orang di sekitarnya atau singkatnya punya beban mental, sedangkan melalui komunitas virtual seseorang lebih leluasa untuk memberikan pendapatnya karena tidak terlihat langsung oleh anggota lainnya.

Keleluasan mengeluarkan pendapat dalam komunitas virtual terkadang berimplikasi menimbulkan kesalahpahaman antaranggota yang berujung pada ujaran kebencian atau peperangan teks dalam ruang virtual. Menurut Rid (2013), 
peperangan di media sosial tidak membutuhkan tempat, tidak mengenal waktu, dan bahkan tidak mengenal dengan baik siapa pihak yang saling berperang.

Peneliti mengidentifikasi ada beberapa hal yang menimbulkan kesalahpahaman dalam komunitas virtual. Pertama, perbedaan dalam intepretasi teks. Kesalahpahaman biasanya muncul akibat perbedaan interpretasi terhadap teks yang dikirim oleh salah seorang anggota komunitas virtual. Perbedaan dalam menginterpretasi pesan terkadang menimbulkan perdebatan antara keduanya, sehingga sering kali berujung pada konflik sosial. Soekanto (1992) menyebut konflik antarindividu yang disebabkan oleh perbedaan pandangan dengan istilah pertentangan pribadi. Di samping itu, terkadang komunikasi menggunakan teks yang berlangsung dalam komunitas virtual tidak sesuai dengan ejaan yang disempurnakan (EYD). Seseorang lebih bebas untuk menuliskan pesan singkatnya sesuai kemauannya sendiri, seperti menulis singkatan dan sebagainya. Keleluasaan memberi singkatan tersebut terkadang menimbulkan interpretasi yang berakhir dengan perang argumen antaranggota dalam komunitas virtual. Kedua, kesalahan penggunaan simbol. Komunikasi dalam komunitas virtual mempunyai kelemahan tersendiri, seperti tidak bisa melihat raut wajah lawan bicaranya. Inovasi media sosial adalah menyediakan aplikasi simbol (emotion) yang mewakili ekspresi wajah dan perilaku seseorang dalam ruang nyata. Seseorang akan memaknai simbol tersebut sebagai representasi lawan bicaranya. Kesalahpahaman antaranggota komunitas virtual salah satunya disebabkan oleh kesalahan penggunaan simbol-simbol tersebut. Simbol yang dikirimkan terkadang membuat anggota lainnya tersinggung dan tersudutkan meskipun terkadang pesan yang memuat simbol tersebut ditarik atau dihapus oleh si pengirim. Namun, ini tidak dapat mengubah efek ketersinggungan anggota terhadap simbol awal yang dikirimkan. Melihat fenomena tersebut, peneliti menganggap sebagai prinsip dasar komunikasi yang bersifat irreversible. Menurut Mulyana (2007), irreversible diartikan bahwa dalam komunikasi sekali pesan dikirimkan maka si pengirim tidak dapat mengendalikan pengaruhnya, apalagi menghilangkan efek pesan tersebut. Pesan yang awal dikirim akan langsung diterima dan dimaknai oleh si penerima. Namun, peneliti mempunyai asumsi lain terhadap konflik kesalahan menggunakan simbol tersebut. Peneliti mengidentifikasi ada variabel lain yang mendorong konflik terhadap kesalahan simbol ini. Variabel itu adalah kondisi psikologis penerima simbol yang sedang tidak stabil sehingga cenderung mudah tersinggung, dan memunculkan ujaran kebencian. Konflik dalam komunitas virtual yang salah satunya disebabkan oleh kondisi psikologis yang tidak stabil akan dijelaskan dalam pembahasan berikutnya. Dengan demikian, simbol atau lebih tepatnya emoticon mungkin menciptakan kesalahpahaman, tapi kondisi psikologis si penerima juga harus diperhatikan. 


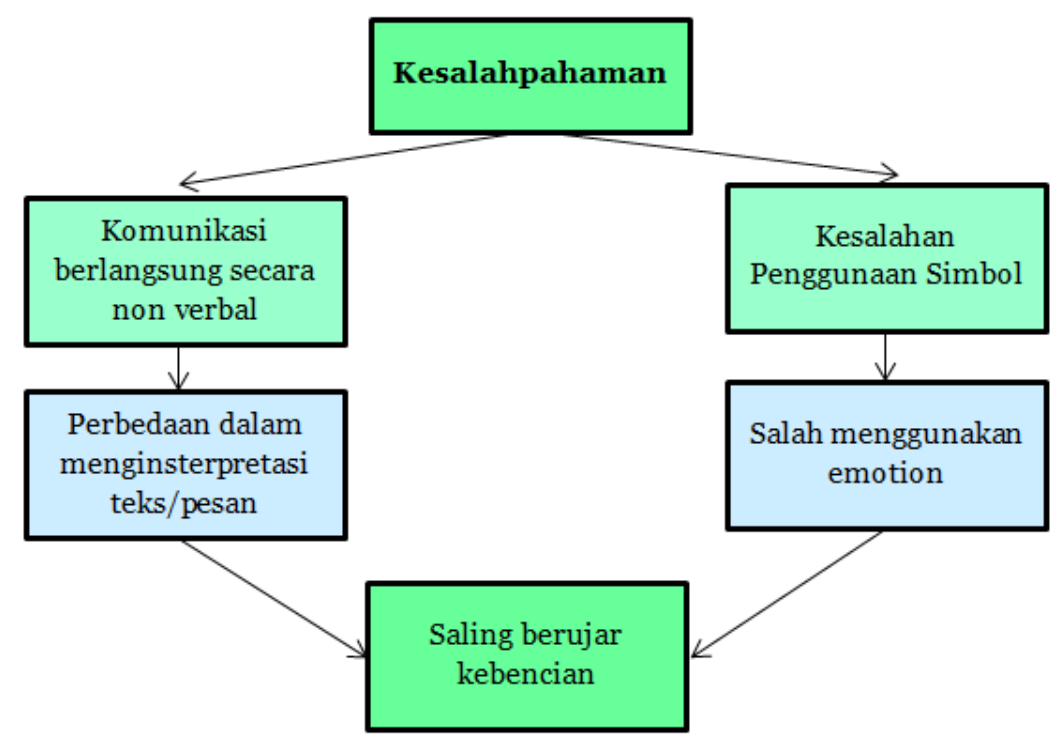

Gambar 1. Konflik di dalam komunitas virtual akibat kesalahpaman dalam memahami teks dan symbol

\section{Sensitivitas dalam komunitas virtual}

Keterbukaan akses pada komunitas virtual mengakibatkan setiap anggotanya berkirim pesan dan melakukan interaksi secara bebas. Di samping itu, setiap anggota bebas merepresentasikan dirinya dalam komunitas virtual sesuai keinginannya. Kebebasan ini yang terkadang membuat beberapa anggota merasa sensitif terhadap postingan atau interaksi dari anggota lainnya.

Ada beberapa konflik dalam komunitas virtual yang disebabkan oleh kesensitivitasan para anggota. Pertama, sensitivitas linguistik. Sensitivitas linguistik yang dimaksud peneliti adalah kemampuan seseorang merespon negatif penggunaan bahasa anggota lainnya dalam komunitas virtual. Keragaman suku, budaya, agama, dan pendidikan yang menyusun sebuah komunitas virtual mengakibatkan terbentuknya heterogenitas sikap dan perilaku anggotanya. Penggunaan bahasa daerah oleh sekelompok anggota dalam komunitas virtual mengakibatkan kesensitivitasan anggota lain yang tidak sesuku ataupun sebudaya. Kesensitivitasan tersebut mengakibatkan beberapa anggota lain melakukan komentar pedas terhadap perilaku anggota yang menggunakan bahasa daerah. Komentar pedas tersebut akhirnya mengakibatkan ketersinggungan antar-anggota sehingga berakhir dengan konflik budaya.

Perbedaan budaya kiranya dapat menjadi sumber konflik. Seperti dikemukakan Narwoko dan Bagong Suyanto (2005), perbedaan kebudayaan tidak hanya akan menimbulkan konflik antar individu, tetapi juga antarkelompok. Polapola kebudayaan yang berbeda akan menimbulkan pola-pola kepribadian dan pola-pola perilaku yang berbeda pula di kalangan khalayak luas. Selain itu, perbedaan kebudayaan akan mengakibatkan adanya sikap etnosentrisme, yaitu sikap yang ditunjukkan kepada kelompok lain bahwa kelompoknya adalah yang paling baik. Jika masing-masing kelompok yang ada dalam kehidupan sosial samasama memiliki sikap demikian, maka akan memicu timbulnya konflik antarpenganut kebudayaan. Soekanto (1992) menyebut fenomena semacam ini sebagai konflik 
pertentangan rasial, yaitu pertentangan yang disebabkan oleh perbedaan ras.

Menurut peneliti, konflik budaya sangat rentan terjadi pada komunitas virtual yang bersifat heterogen, sedangkan komunitas virtual yang bersifat homogen cenderung terhindar dari konflik budaya. Komunitas virtual heterogen cenderung sulit untuk menyatukan persepsi anggotanya, sedangkan komunitas virtual homogen cenderung mudah untuk menyatukan persepsi anggotanya.

Peneliti dapat memberikan contoh tentang komunitas virtual yang bersifat heterogen seperti komunitas virtual alumni (terdiri dari satu almamater, tetapi mempunyai bermacam suku, budaya dan agama di dalamnya), komunitas virtual keorganisasian kampus (terbentuk dari visi dan misi yang sama, tapi setiap anggota mempunyai latar belakang yang berbeda) dan sebagainya. Komunitas virtual yang bersifat homogen seperti komunitas virtual masyarakat minang (terdiri dari suku dan budaya yang sama), komunitas virtual English club (terdiri dari beberapa anggota yang memiliki minat bahasa yang sama), dan sebagainya. Meskipun demikian, menurut peneliti, akan sulit mendeteksi komunitas virtual yang bersifat homogen secara totalitas. Ini terjadi karena homogitas dan heterogenitas sering kali tumpang tindih. Dalam konteks sensitivetas linguistik, standar kehomogenitasannya terletak pada bahasa.

Kedua, sensitivitas timing. Sensitivitas timing yang dimaksud peneliti adalah kemampuan seseorang untuk merespon negatif waktu aktivitas dalam komunitas virtual. Ketidakjelasan aturan baku dalam komunitas virtual mengakibatkan setiap anggota bebas mengirim informasi atau melakukan interaksi kapan saja dalam komunitas virtual. Ketidakterikatan waktu untuk melakukan aktivitas dalam komunitas virtual ini mengakibatkan kesensitivitasan anggota lainnya.

Beberapa anggota terkadang melakukan interaksi dalam komunitas virtual hingga larut malam sehingga mengganggu waktu istirahat anggota lainnya. Atas ketidaknyamanan itu, beberapa anggota melakukan teguran dengan melontarkan kalimat yang menyinggung sehingga antaranggota saling berujar kebencian, dan berakhir dengan kesalahpahaman yang membuat konflik antara keduanya. Dengan demikian, ujaran kebencian muncul karena ketidaktepatan waktu pengiriman informasi (posting) dengan kondisi psikologi anggota lainnya sehingga menimbulkan interpretasi yang negatif. Postingan yang dikirim pada saat anggota lain sedang sibuk akan berbeda interpretasinya dibandingkan dalam keadaan santai. Kevirtualitasan inilah yang mengakibatkan setiap anggota tidak bisa mengidentifikasi kondisi psikologi anggota lainnya. Kesalahan timing dalam aktivitas komunitas virtual inilah yang pada akhirnya mengakibatkan kesensitivitasan anggota lainnya.

Ketiga, sensitivitas community functions. Sensitivitas community functions yang dimaksud peneliti adalah kemampuan seseorang untuk merespon negatif aktivitas yang bertentangan dengan fungsi komunitas virtual. Interaksi dalam komunitas virtual idealnya dilakukan untuk kepentingan komunitas. Namun, beberapa anggota melakukan interaksi yang bersifat pribadi yang idealnya dilakukan di ruang pribadi (personal space). Perilaku ini sering ditanggapi dengan teguran-teguran yang pada akhirnya menimbulkan kesalahpahaman dan terjadi konflik di antara keduanya. Pelaku chat pribadi merasa bahwa dirinya sedang berinteraksi dengan sesama anggota komunitas juga, tetapi tidak menyadari bahwa interaksinya memuat 
unsur pribadi yang menimbulkan sensitivitas bagi anggota lainnya.

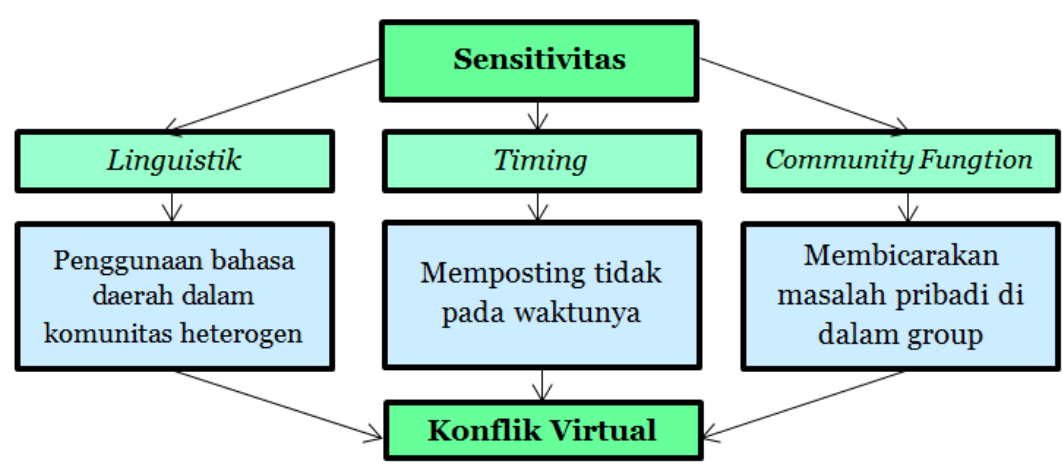

Gambar 2. Sensitivitas menyebabkan konflik di dalam komunitas virtual

\section{Cyberbullying}

Komunitas virtual tidak hanya dijadikan sebagai sarana berkirim informasi, tapi juga sebagai sarana menghibur diri dan bercanda bersama anggota lainnya. Candaan di dalam komunitas virtual biasanya dilampiaskan dalam bentuk tindakan ejekan atau menyebar gambar-gambar yang mempermalukan anggota lainnya sehingga pada akhirnya menimbulkan perilaku saling bully atau mengejek satu sama lain. Perilaku saling mengejek di ruang virtual di sebut dengan cyberbullying. Menurut Hertz (2008), cyberbullying adalah bentuk penindasan atau kekerasan dengan bentuk mengejek, mengatakan kebohongan, melontarkan kata-kata kasar, menyebarkan rumor maupun melakukan ancaman atau berkomentar agresif yang dilakukan melalui media-media seperti email, chat room, pesan instan, website (termasuk blog) atau pesan singkat (SMS).

Di samping itu, secara umum, media sosial merupakan tempat yang paling sering digunakan untuk menyebarkan virus bullying. Hal ini mengacu pada hasil penelitian Whittaker dan Robin M. Kowalski (2015). Penelitian ini juga menunjukkan bahwa salah satu penyebab konflik dalam komunitas virtual adalah perilaku bullying. Interaksi yang berawal dari sebuah candaan berlanjut menjadi interaksi saling mengejek antaranggota sehingga pada akhirnya salah seorang anggota merasa tersudutkan dan berujung saling menghujat satu sama lain.

Keagresifan melakukan bullying dalam komunitas virtual mengakibatkan pola interaksi yang awalnya candaan menjadi saling berujar kebencian. Studi Whittaker dan Robin M. Kowalski (2015) menyebutkan bahwa komentar yang agresif mempengaruhi persepsi munculnya cyberbullying.

Peneliti mengidentifikasi bahwa pada dasarnya setiap anggota dalam komunitas virtual selalu menjaga image atau citra baik di hadapan anggota lainnya. Pretuce (2006) menyebutkan bahwa media sosial digunakan sebagai cara untuk mempromosikan dan membuat personal branding mereka untuk selalu menampilkan dirinya yang terbaik di ruang maya sehingga bullying dalam komunitas virtual sering berujung pada konflik antaranggota. Ini karena bully yang dilakukan anggota lainnya telah merusak image personalnya. Di samping itu, dalam komunitas virtual, informasi akan cepat menyebar sehingga hal ini menjadi beban moral tersendiri bagi korban cyberbullying. 


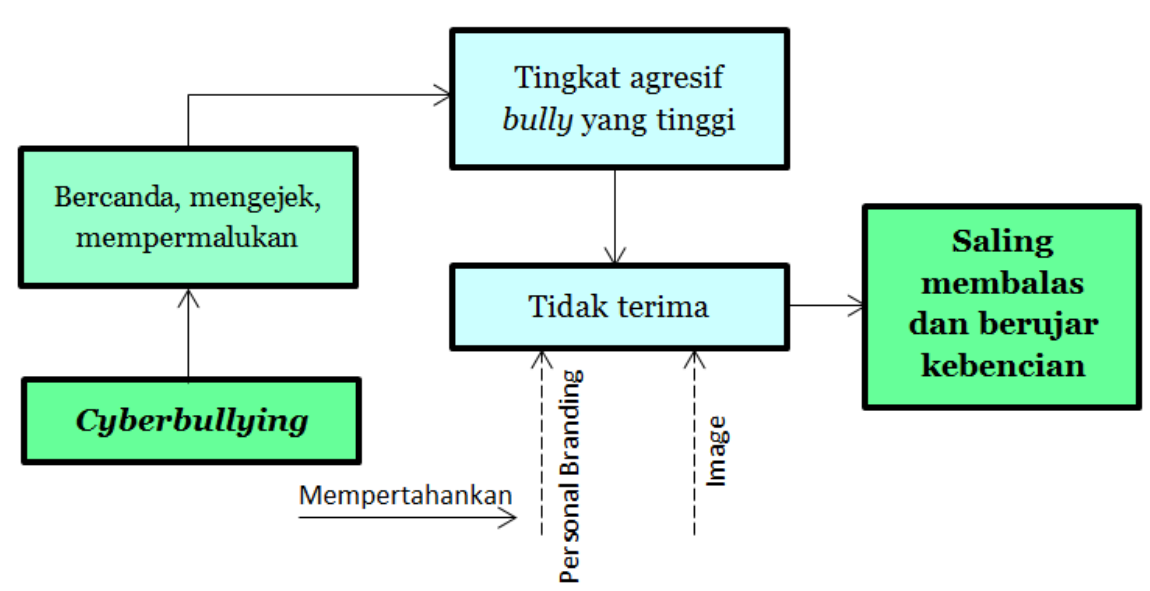

Gambar 3. Cyberbullying menyebabkan konflik di dalam komunitas virtual

\section{Postingan Isu SARA dalam Komunitas Virtual}

Isu-isu SARA (suku, agama, ras, dan antargolongan) sangat akrab di media sosial sehingga terkadang isu-isu tersebut menjadi bahan perbincangan dalam komunitas virtual. Beberapa informan dalam penelitian ini menyebutkan bahwa postingan tentang isu-isu SARA juga bisa menimbulkan konflik dalam komunitas virtual. Salah satu informan mengemukakan, "Menurut saya penyebab konflik di group whatsapp adalah perbedaan pendapat terhadap postingan yang mengandung SARA, seperti video gif Habib Rizieq yang sempat kontroversial (Wawancara dengan E).”

Kutipan di atas menunjukkan bahwa postingan isu-isu SARA seperti video gif Habib Rizieq menjadi isu hangat yang diperbincangkan. Postingan video gif Habib Rizieq menimbulkan perbedaan pandangan antaranggota dalam komunitas virtual tersebut. Video yang sangat kontroversial tersebut mengakibatkan anggota komunitas virtual terfragmentasi menjadi tiga kelompok, yakni kelompok yang menerima postingan, kelompok yang menolak dan meragukan postingan, dan menerima postingan berdasarkan kekompleksitasan isu.
Kelompok penerima postingan menganggap bahwa postingan tersebut merupakan aksi solidaritas terhadap pelecehan ulama oleh oknum tertentu. Dalam penelitian Syahputra (2017), kelompok ini disebut sebagai kelompok konservatif. Kelompok konservatif yang dengan mudah dan cepat merespon opini, informasi dan isu yang dianggap memojokkan umat Islam di media sosial. Dalam kasus pemilihan kepala daerah (Pilkada) DKI Jakarta 2017, dikenal dengan aksi bela Islam (ABI). Menurut peneliti, anggota yang menerima postingan dan membuka gif tersebut karena merasa terpanggil dengan gerakan konservatif ini. Singkatnya, media telah mengkonstruksi pemirsa melalui aksi bela Islam. Di samping itu, gif tersebut berhubungan dengan seorang ulama (Habib Rizieq) yang oleh Syahputra (2017) disebut sebagai opinion marker tentang penistaan agama di media sosial.

Kelompok yang menolak dan meragukan postingan, di sisi lain, adalah kelompok liberal. Mengacu pada Syahputra (2017), kelompok ini disebut kelompok liberal yang meragukan sistem yang berlaku. Kelompok ini menganggap bahwa postingan tersebut hanya usaha oknum tertentu untuk mencari keuntungan material dan non material melalui gif Habib Rizieq dengan asumsi 
semakin banyak yang membuka gif tersebut, maka semakin banyak pula keuntungan yang diperoleh. Kelompok tersebut beranggapan bahwa seharusnya gif tersebut tidak diposting dalam komunitas virtual.

Kelompok terakhir adalah yang menerima postingan tergantung pada kekompleksitasan isu. Kelompok ini cenderung menjadi kelompok silent reader (pembaca diam), dan lebih berperan sebagai pembaca dan penilai isu-isu yang diposting oleh anggota lainnya. Kelompok ini tidak ingin terlibat dalam kedua kelompok sebelumnya.

Pada dasarnya, kelompok liberal dan konservatif mempunyai kecenderungan yang sama untuk melakukan aksi bela ulama melalui gif yang berkembang di ruang virtual, tetapi model atau perspektifnya bertolak belakangan antara keduanya. Kelompok silent reader, di sisi lain, cenderung berada pada posisi aman (antara membela dan tidak membela). Kelompok silent reader cenderung mengakui berita hoax.

Hoax atau pemberitaan palsu atau fake news adalah usaha untuk menipu atau mempengaruhi pembaca untuk meyakini sesuatu yang tidak jelas kebenarannya. Pada saat ini, hoax syarat dengan muatan politis (UI Lib, 2017). Kelompok silent reader meyakini bahwa gif Habib Rizieq merupakan hoax karena beberapa alasan tertentu

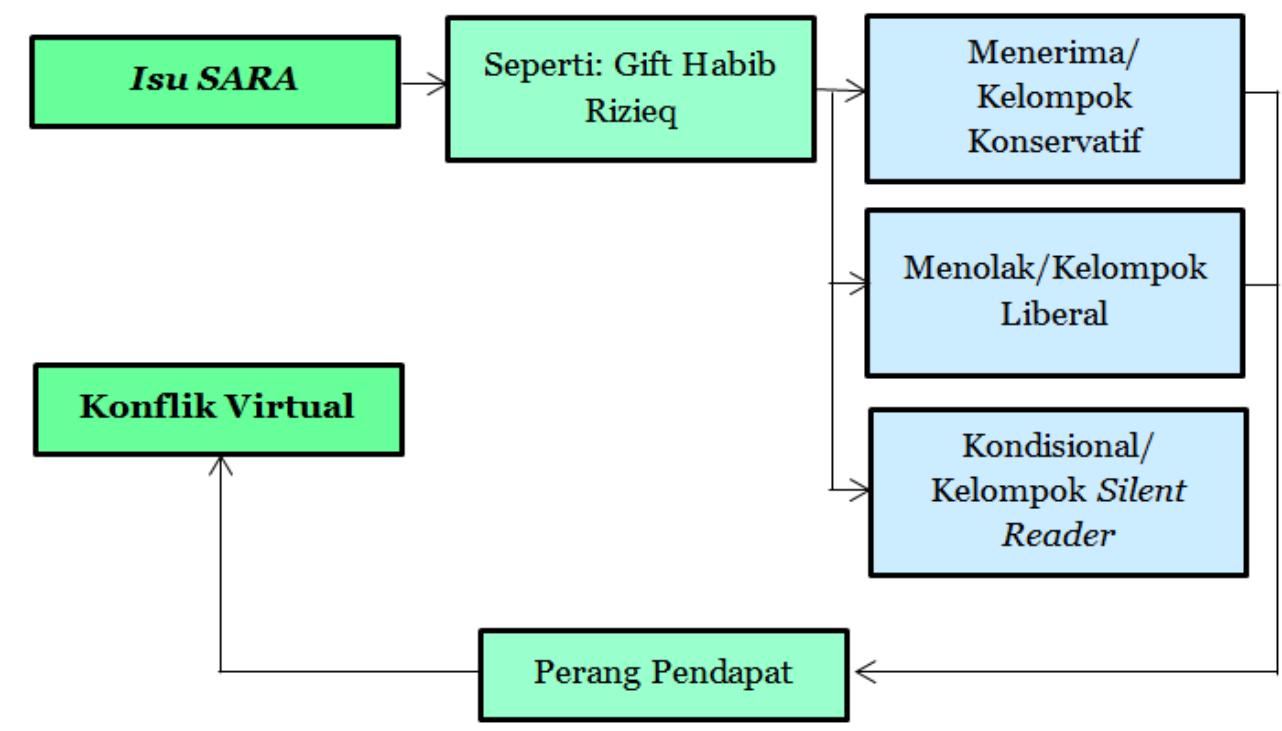

Gambar 4. Postingan isu SARA menyebabkan konflik di dalam komunitas virtual

\section{Egosentris dalam komunitas virtual}

Egosentris tidak dapat dipisahkan dalam kehidupan individu. Egosentris adalah sikap mementingkan diri sendiri dan tidak dapat memahami orang lain. Shaffer (2009) menyebutkan egosentris sebagai kecenderungan seseorang untuk melihat dunia dari perspektifnya sendiri dan enggan untuk memahami orang lain.
Dalam komunitas virtual, egosentris menjadi faktor utama yang menimbulkan konflik. Seperti dijelaskan di awal, setiap anggota dalam komunitas virtual cenderung menjaga personal branding-nya sehingga terkadang mempertahankan pendapatnya walaupun salah demi menjaga nama baiknya di hadapan anggota komunitas virtual lainnya. Sikap mempertahankan pendapat- 
nya (egoisme) kerap sekali menimbulkan konflik di antara mereka sehingga saling berujar kebencian. Informan penelitian menyampaikan hal yang sama sebagai berikut.

Anggota grup yang menjadikan dirinya sentral akan memaksakan kehendak dirinya, menganggap pemikirannya paling benar, sulit diarahkan, tidak mau mengalah. Sehingga ketika berdiskusi atau berkordinasi di dalam grup akan mengundang kekesalan anggota grup lainnya. Apabila anggota yang geram ini tidak mampu menahan diri maka akan melontarkan kalimatkalimat yang kasar (Wawancara dengan $N$ ).

Kutipan dari informan di atas menunjukkan bahwa sifat egoisme terkadang dipengaruhi oleh latar belakang seseorang. Dalam komunitas virtual, perbedaan latar belakang pendidikan, suku, budaya, dan sebagainya mencerminkan pendapatnya di ruang komunitas tersebut. Pendapat setiap anggota selalu bercermin dari pengalaman dan latar belakang yang dialaminya sehingga terkadang setiap anggota mempunyai ego tersendiri dalam mempertahankan pendapatnya. Perbedaan latar belakang dalam mengungkapkan pendapat di ruang virtual tersebut yang rentan menimbulkan sikap egosentris hingga berakhir dengan konflik antaranggota dalam komunitas virtual. Tidak jarang pula, ada salah seorang anggota yang tidak senang membaca kiriman atau pendapat anggota lainnya. Inilah yang menyebabkan komunitas virtual juga mengancam persahabatan anggotanya. Hasil penelitian Dasuki (2016) menunjukkan bahwa, pada satu sisi, kehadiran media sosial dapat memberikan kemudahan bagi masyarakat, tetapi, di sisi lain, dapat menghancurkan kersamaan dan kemajemukan Bangsa Indonesia.

Konflik dalam komunitas virtual cenderung pada perang ideologi atau perang pendapat, sedangkan konflik di ruang nyata dapat mengarah pada perang fisik. Lauer (2001) menyebutnya sebagai konflik konstruktif, yaitu konflik yang bersifat fungsional. Konflik ini muncul karena adanya perbedaan pendapat dari kelompokkelompok dalam menghadapi suatu permasalahan. Konflik ini akan menghasilkan suatu konsensus dari berbagai pendapat tersebut dan menghasilkan suatu perbaikan, misalnya, perbedaan pendapat dalam sebuah organisasi. Di samping itu, konflikkonflik yang terjadi dalam komunitas virtual cenderung dilakukan oleh anggota yang sebaya. Kusnadi (2002) menyebutnya dengan konflik horizontal. Konflik horizontal merupakan konflik yang terjadi antara individu atau kelompok yang memiliki kedudukan yang relatif sama. Menurut peneliti, sifat egosentris para anggota cenderung didasarkan pada usaha mempertahankan personal branding-nya di hadapan anggota lainnya. Ketidakbakuan aturan dalam komunitas virtual juga berimplikasi pada kesewenang-wenangan (egoisme) anggota untuk melakukan aktivitas di dalam komunitas virtual. 


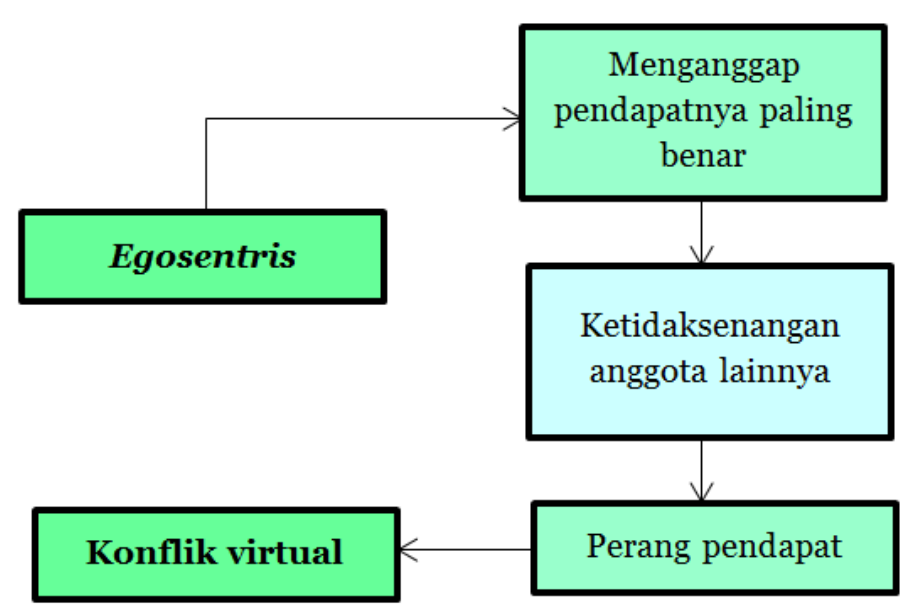

Gambar 5. Egosentris menyebabkan konflik di dalam komunitas virtual

\section{Dampak konflik dalam komunitas virtual}

Seperti dampak konflik pada umumnya, konflik dalam komunitas virtual juga mempunyai dua dampak, yaitu dampak positif dan dampak negatif. Dampak negatif berdasarkan konflik yang terjadi dalam komunitas virtual di antaranya antarpelaku konflik tidak bertegur sapa di dalam group maupun di dalam ruang nyata. Pelaku konflik akan kehilangan kepercayaan diri dalam komunitas virtual tersebut. Menurut Setiadi dan Usman Kolip (2011), dampak seperti itu disebut dengan perubahan kepribadian individu. Perubahan kepribadian individu itu tercermin dari yang awalnya anggota percaya diri untuk berpendapat dan memposting isu-isu tertentu kemudian menjadi pribadi yang pendiam. Di samping itu, terjadi kesenjangan dalam group sehingga group akan sunyi dalam beberapa waktu.

Konflik tidak selamanya berdampak negatif, terkadang konflik mempunyai dampak yang positif. Coser (1964) menyebut konflik berkontribusi terhadap pembentukan dan penegasan kembali identitas kelompok. Dampak positif konflik dalam komunitas virtual adalah membuat norma-norma baru dalam komunitas virtual, seperti aturan memposting dan sebagainya. Di samping itu, dengan adanya konflik yang terjadi dalam komunitas virtual, hubungan antaranggota menjadi lebih harmonis. Biasanya, anggota lainnya akan mem-bully para pelaku konflik setelah konflik mulai mereda sehingga menimbulkan rasa solidaritas yang lebih tinggi. Mengacu pada Narwoko dan Bagong Suyanto (2005), dampak positif terjadinya konflik yaitu bertambahnya solidaritas intern dan rasa in-group suatu kelompok.

\section{Manajemen konflik dalam komunitas virtual}

Peneliti memberikan rekomendasi tentang cara penyelesaian konflik (manajemen konflik) dalam komunitas virtual dengan mengacu pada Nasikun (2003). Menurutnya, bentuk penyelesaian konflik yang lazim dipakai, yakni konsiliasi, mediasi, arbitrasi, koersi (paksaan), detente (mengurangi ketegangan atau perdamaian).

Penyelesaian konflik dengan cara konsiliasi dalam komunitas virtual dilakukan dengan melakukan pertemuan secara nyata antara pihak yang berkonflik dengan dibantu konsiliator, yang dalam hal 
ini adalah orang yang dituakan, admin atau orang yang berpengaruh. Di samping itu, cara penyelesaian konflik dalam komunitas virtual dilakukan dengan metode mediasi. Mediasi dilakukan dengan keterlibatan anggota dalam komunitas tersebut dengan mendudukkan akar permasalahannya. Mediasi ini dilakukan baik secara virtual maupun nyata. Cara penyelesaian konflik seperti ini disebut oleh Thomas dan Killman (dalam Wirawan, 2010) dengan istilah kolaborasi dan kompromi. Ini berarti bahwa setiap orang yang berkonflik secara bersama memenuhi apa yang menjadi tuntutannya untuk mendapatkan alternatif bersama.

Cara penyelesaian konflik dalam komunitas virtual juga dapat dilakukan dengan koersi (paksaan). Paksaan yang dimaksud adalah mengeluarkan anggota yang berkonflik untuk sementara waktu dari komunitas virtual mereka. Koersi merupakan peran utama admin terhadap konflik yang terjadi dalam komunitas virtual tersebut. Namun, terkadang yang menjadi persoalan adalah peran admin yang tidak peka dalam menanggapi konflik dalam komunitas virtual tersebut. Kemudian setelah konflik meredah, admin mengundang kembali pihak yang berkonflik ke dalam komunitas virtual tersebut.

Manajemen konflik lainnya dengan menggunakan metode detente (mengurangi ketegangan). Metode detente dilakukan dengan cara anggota lainnya mengalihkan pembicaraan, dan beberapa anggota memposting gambar-gambar lucu ke dalam group sehingga mengundang tawa anggota lainnya. Di samping itu, beberapa anggota juga memilih untuk menjadi silent reader dengan asumsi tidak ingin membuat konflik semakin memanas dan tidak ingin terlibat dalam konflik tersebut.

\section{Kesimpulan}

Komunitas virtual tidak hanya memudahkan seseorang untuk berinteraksi, berkirim pesan dan saling menyapa dengan anggota lainnya. Namun, komunitas virtual juga cenderung mengindikasikan penyebab terjadinya kesenjangan atau konflik antaranggota di dalamnya. Beberapa konflik yang terjadi dalam komunitas virtual disebabkan oleh beberapa hal, di antaranya kesalahpahaman memahami teks atau pendapat di dalam ruang interaksi virtual; sensitivitas terhadap simbol, timing dan fungsi komunitas (community function); cyberbullying yang berakhir pada ketersinggungan; kiriman (postingan isu SARA) dalam komunitas virtual sehingga mengakibatkan anggota terfragmentasi menjadi tiga kelompok, yaitu kelompok konservatif, liberal dan silent reader; dan egosentris dalam komunitas virtual yang disebabkan oleh perbedaan latar belakang anggota.

Dampak yang ditimbulkan konflik dalam komunitas virtual, yaitu dampak positif yang berimplikasi pada semakin tingginya tingkat solidaritas anggota; dan dampak negatif yang berimplikasi pada perubahan kepribadian individu dan kesenjangan dalam komunitas virtual.

Penyelesaian konflik dalam komunitas virtual dapat dilakukan dengan konsiliasi antarpelaku konflik, mediasi, mengeluarkan pelaku dari komunitas virtual untuk sementara waktu hingga melakukan detente dengan cara mengalihkan pembicaraan atau mengirim gambargambar yang mengundang tawa anggota lainnya.

Kecenderungan konflik yang terjadi dalam komunitas virtual pada dasarnya disebabkan oleh kebebasan menyampaikan pendapat melalui ruang virtual. Singkatnya, konflik terjadi karena ketidakmampuan memposisikan diri dalam 
komunitas virtual sebagai media interaksi bersama yang mempunyai keterbatasan.

Kesimpulan penelitian menegaskan pentingnya etika komunikasi bagi para partisipan komunikasi atau emphatic communication, terutama dalam komunitas-komunitas virtual yang beragam. Meskipun penelitian ini menemukan cara- cara menyelesaikan konflik dalam komunitas virtual, tapi "komunikasi virtual" dengan etika dapat meminimalkan konflik di antara mereka. Oleh karena itu, perlu didorong penelitian-penelitian dalam bentuk partisipasi observasi ataupun etnografi virtual untuk mengungkap lebih dalam dinamika komunikasi yang berlangsung dalam komunitas virtual

\section{DAFTAR PUSTAKA}

Buku

Bungin, Burhan. (2000). Penelitian Kualitatif, Komunikasi, ekonomi, kebijakan public dan ilmu sosial lainnya. Jakarta: Kencana.

Coser, Lewis A. (1964). The Functions of Social Conflict. New York, NY: Free Press.

Gunawan, Imam. (2014). Metode Penelitian Kualitatif Teori dan Praktik. Jakarta: Bumi Aksara.

J. Dwi Narwoko dan Bagong Suyanto. (2005). Sosiologi Teks Pengantar dan Terapan. Jakarta: Kencana Prenada Media Group.

Jasmadi. (2008). Membangun Komunitas Online Secara Praktis dan Gratis. Jakarta: Elex Media Komputindo.

Kusnadi. (2002). Masalah Kerja Sama, Konflik dan Kinerja. Malang : Taroda.

Laudon, Kenneth C and Carol Guercio Traver. (2016). E-Commerce: Business, Technology, Society. Twelfth Edition. England: Pearson Education Limited.

Mayfield, Antony. (2008). What is Social Media?, an e-book by Antony Mayfield from I Crossing, V 1.4 updated 01.08.08
Mulyana, Deddy. (2007). Ilmu Komunikasi: Suatu Pengantar. Bandung: Remaja Rosdakarya.

Nasikun. (2003). Sistem Sosial Indonesia. Jakarta: PT. Raja Grafindo Persada.

Rid, Thomas. (2013). Cyber War will not Take Place. London: Hurst/Oxford Press

Lauer, Robert H. (2001). Perspektif Tentang Perubahan Sosial. Jakarta : PT. Rineka Cipta.

Setiadi, Elly M. dan Usman Kolip. (2011). Pengantar Sosiologi Pemahaman Fakta dan Gejala Permasalahan Sosial: Teori, Aplikasi, dan Pemecahannya. Jakarta: Kencana Prenada Media Group.

Shaffer, David R. (2009). Social and Personality Development. 6 edition. Wadsworth: Cengage Learning.

Soekanto, Soerjono. (1992). Sosiologi Suatu Pengantar. Jakarta: Rajawali Pers.

Stokes, J. (2006). How to do Media and Cultural Studies. London: Sage.

Subagyo, P.Joko. (2011). Metode Penelitian dalam Teori dan Praktik. Jakarta: Rineka Cipta. 
Hancock, B., Ockleford, E., \& Windridge, K. (2009). An Introduction to Qualitative Research. Yorkshire, UK: The National Institute Health Research for Yorkshire and the Humber.

Hammersley, M., \& Atkinson, P. (2007). Ethnography: Principles in Practice (3rd ed). London; New York: Routledge.

Wirawan. (2010). Konflik dan Manajemen Konflik: Teori. Aplikasi dan Penelitian. Jakarta: Salemba Humanika.

Wimmer, R.D and Dominick, J.R. (2014). Mass Media Research an Introduction. Wadsworth: Cengage Learning.

\section{Jurnal:}

Aditya, Rangga. (2015). Pengaruh Media Sosial Instagram Terhadap Minat Fotografi Pada Komunitas Fotografi Pekanbaru. Jurnal Komunikasi, 2(2) Universitas Riau.

Dasuki, Muhammad Ramdon. (2016). Media Sosial: Antara Kebutuhan dan Ancaman, 8(2), 14.

Petruce, Irine. (2016). Personal Branding Through Social Media. International Journal of Communication Research, 6(4), 389-392.
Simangunsong, B. A. (2017). Interaksi Antarmanusia Melalui Media Sosial Facebook Mengenai Topik Keagamaan. Jurnal ASPIKOM, 3(1), 65-76.

Syahputra, Iswandi. (2017). Demokrasi Virtual dan Perang Siber di Media Sosial: Perspektif Netizen Indonesia. Jurnal ASPIKOM, 3(3), 97-116.

UI Lib. (2017). Stop Hoax. Berkala, 3(1), 128.

Weeks, B.E. and Holbert, R.L. (2013). Predicting Dissemination of Newsc Content in Social Media: A Focus on Reception, Friending and Partisanship. Journalism and Mass Communication Quaterly, 90 (2), 12.

Whittaker, Elizabeth and Robin M. Kowalski. (2015). Cyberbullying Via Social Media. Jurnal of Scholl Violence, 14 (1), 11.

\section{Website:}

APJII: Infografis Panetrasi dan Perilaku Pengguna Internet di Indonesia. (2017). Tersedia dari: https://apjii.or.id/survei2017/kiri mlink, diakses 31 November 2018.

Stockdale, Rosemary dan Michael Borovicka (2006). Developing an Online Business Community: A Travel Industry Case Study. Diterbitkan oleh System Sciences, 2006. HICSS '06. Prosiding Konferensi Internasional Hawaii ke39 di Indonesia. Tersedia dari: https://fba.aiub.edu/Files/Uploads/ MGT110040. pdf, diakses pada 25 Mei $\underline{2018}$ 
Jurnal komunikasi, Volume 13, Nomor 2, April 2019, Hal 135-150 